\title{
OBSŁUGA KLIENTA DETALICZNEGO W PROCESIE KREDYTOWYM
}

\author{
Katarzyna Nowak \\ Wydział Zarządzania \\ Uniwersytet Ekonomiczny w Krakowie
}

\begin{abstract}
Streszczenie
Warunki podjęcia właściwej decyzji kredytowej przez konsumenta kształtuje nie tylko cena, ale także obsługa w banku. Rzetelnie i prawidłowo przeprowadzona obsługa klienta w procesie kredytowym jest $w$ interesie kredytodawcy $i$ kredytobiorcy. Może ona zabezpieczyć obie strony umowy kredytu przed negatywnymi konsekwencjami. Konsumenta przed nadmiernym zadłużeniem i kłopotami finansowymi, a bank przed brakiem spłaty zobowiązania. Jakość obsługi ma szczególne znaczenie dla słabszej strony umowy - klienta detalicznego. Celem artykułu jest ocena praktyki banków w zakresie obsługi klienta detalicznego na etapie przedkontraktowym w procesie kredytowym. W artykule dokonano analizy jakości i rzetelności obsługi klienta detalicznego i realizacji obowiązków przedkontraktowych w głównych bankach w 2017 r. Wnioski z przeprowadzonych badań wskazują na występowanie licznych nieprawidłowości w trakcie obsługi klientów leżących po stronie banków. Konkluzje zawarte w artykule potwierdzają, że banki w procesie kredytowym nie biorą pod uwagę w wystarczającym stopniu interesów konsumentów i nie wywiązują się z wszystkich obowiązków przedkontraktowych.
\end{abstract}

Słowa kluczowe: kredyt konsumencki, obsługa w banku, obowiązki informacyjne, obowiązki przedkontraktowe, ochrona konsumenta, proces kredytowy.

JEL Class: G21, G28, K12. 


\section{WPROWADZENIE}

Niniejsza publikacja dotyczy jakości obsługi klienta detalicznego w procesie kredytowym. Warunki podjęcia właściwej decyzji przez konsumenta kształtuje nie tylko cena kredytu, ale także obsługa w banku. Bank poprzez postępowanie pracowników może klientowi ułatwiać bądź utrudniać podjęcie właściwej decyzji. Obsługa klienta jest wyrazem stosunku banku do klienta i rzeczywistej troski o klienta, na którą tak często banki lubią się powoływać. Wysoka jakość obsługi klienta, fachowość w diagnozowaniu jego potrzeb wpływają na satysfakcję klienta i jego zadowolenie z otrzymanego produktu i realizacji umowy. Jakość obsługi, w tym budowanie relacji i dbanie o klienta w kluczowych dla niego momentach pozwala bankom na wyróżnienie się na rynku i stanowi źródło przewagi konkurencyjnej.

Celem artykułu jest przedstawienie i ocena praktyki banków w zakresie obsługi klienta detalicznego na etapie przedkontraktowym w procesie kredytowym. Autor publikacji analizuje jakość i rzetelność obsługi w banku wobec klienta detalicznego $\mathrm{w}$ procesie kredytowym w wybranych bankach oraz poziom realizacji ustawowych obowiązków kredytodawcy w systemie asysty przedkontraktowej. W artykule dokonano identyfikacji głównych nieprawidłowości występujących w trakcie obsługi klientów detalicznych leżących po stronie banków. Artykuł został oparty na raportach badań instytucji badawczych, literaturze przedmiotu oraz badaniach własnych.

Studia literatury przedmiotu pozwoliły na postawienie tezy, iż banki w procesie kredytowym $\mathrm{w}$ trakcie obsługi klientów detalicznych nie biorą pod uwagę w wystarczającym stopniu interesów konsumentów i nie wywiązują się z wszystkich obowiązków przedkontraktowych, dlatego udzielane informacje, przekazywane dane i wyjaśnienia nie są dla klientów (konsumentów) wystarczające w podejmowaniu właściwych decyzji finansowych.

\section{PODSTAWA PRAWNA ASYSTY PRZEDKONTRAKTOWEJ W KREDYCIE KONSUMENCKIM}

Ochrona konsumenta jest realizowana przez odpowiednią przedkontraktową informację przede wszystkim o treści umowy, przyznanie mu szczególnych uprawnień umownych, a także przez nadanie przepisom chroniącym jego interesy charakteru imperatywnego [Gnela 2012: 163]. Obowiązki przedkontraktowe kredytodawcy wobec kredytobiorcy, takie jak udzielanie określonych informacji i wyjaśnień konsumentowi przed zawarciem umowy o kredyt konsumencki, mają charakter ustawowy. Reguluje je Ustawa o kredycie konsumenckim [Ustawa z dnia 12 maja 2011 r..., Dz.U. 2018, poz. 993 ze zm.], będąca efektem 
wdrożenia do polskiego prawa dyrektywy 2008/48/WE [Dyrektywa Parlamentu Europejskiego i Rady 2008/48/WE z dnia 23 kwietnia 2008 r..., Dz.U. 2014, poz. 1497].

Przepisy regulujące obowiązki kredytodawcy o charakterze informacyjnym w stosunku do konsumenta tworzą normatywny system tzw. asysty przedkontraktowej. Art. 11 ustawy o kredycie konsumenckim wprowadza jeden z podstawowych elementów tego systemu. Zgodnie z nim kredytodawca lub pośrednik kredytowy zobowiązany jest przed zawarciem umowy o kredyt konsumencki udzielić konsumentowi wyjaśnień dotyczących treści informacji przekazywanych przed zawarciem umowy oraz postanowień zamieszczonych $\mathrm{w}$ umowie, która ma zostać zawarta.

Obowiązek udzielenia konsumentowi wyjaśnień podmiotowo zawsze obciąża kredytodawcę lub pośrednika kredytowego. Nie jest w jakikolwiek sposób uzależniony od wniosku lub pytania składanego przez konsumenta. Obowiązek ten wynika wprost z przepisów ustawy i powinien być realizowany bez wezwania przez kredytodawcę lub pośrednika kredytowego [Ofiarski 2014]. Z literatury przedmiotu na temat postaci zachowań informacyjnych [Szaraniec 2017: 166; Tereszkiewicz 214: 135] wynika, że obowiązek udzielenia wyjaśnień to inaczej obowiązek udzielenia wskazówek, tłumaczenia i objaśnień prezentujących produkt lub usługę. Wyjaśnienia jednak nie mogą być związane z udzielaniem rad lub przekonywaniem przez obsługę banku, która oferta jest najlepiej dopasowana do potrzeb i sytuacji finansowej konsumenta. Obowiązek wyjaśnienia obejmuje wszelkie informacje, które zostały przekazane konsumentowi przed zawarciem umowy bez względu na sposób i formę ich przekazania. Ustawodawca nie precyzuje sposobu i metod udzielania wyjaśnień przez bank. Wskazuje, że należy ich udzielać w sposób umożliwiający konsumentowi podjęcie świadomej decyzji dotyczącej umowy o kredyt konsumencki. Natomiast tryb udzielania wyjaśnień powinien być dostosowany do percepcji danego klienta [Ofiarski 2014]. Dlatego kredytodawca powinien w sposób odpowiedni przekazywać informacje konsumentowi uwzględniając jego wiedzę i zakres pojmowanych informacji, czyli wyjaśnienia te powinny być zindywidualizowane.

Udzielanie przez kredytodawców i pośredników kredytowych konsumentom odpowiednich wyjaśnień obejmuje objaśnianie [Tereszkiewicz 2009: 15-23]:

- informacji udzielanych przed zawarciem umowy zgodnie z informacjami, które znajdują się w formularzu informacyjnym,

- głównych cech proponowanych produktów,

- skutków dla konsumenta, jakie mogą one za sobą pociągać.

Celem powyższych objaśnień jest umożliwienie konsumentowi dokonania oceny, czy proponowane warunki kredytu są dostosowane do jego potrzeb i sytuacji finansowej. Wyjaśnienia powinny stanowić dodatkową pomoc umoż- 
liwiającą konsumentowi podjęcie decyzji dotyczącej zawarcia umowy o kredyt konsumencki [Tereszkiewicz 2012: 347-365].

Przepis ten wprowadza wymóg odpowiedniego poinformowania [Czapliński 2012: 7, dostęp: 07.05.2018] w celu lepszego zrozumienia przez konsumenta oferty kredytu, ale również zapewnienia klientowi bezpieczeństwa, że kredytodawca nie wprowadził w błąd konsumenta co do warunków, na jakich kredyt ma zostać udzielony. W celu zapewnienia ochrony konsumentowi zobowiązuje się kredytodawców do wręczenia konsumentom przed zawarciem umowy formularza informacyjnego według wystandaryzowanego formatu [Poradnik dla konsumentów. Kredyt..., 2012: 4, dostęp: 10.05.2018].

Reasumując, system asysty przedkontraktowej ma umożliwić klientowi podjęcie świadomej i racjonalnej decyzji w sprawie zaciągnięcia kredytu oraz wyboru adekwatnej do jego potrzeb oferty kredytowej. Należy podkreślić, że to konsument, a nie kredytodawca czy pośrednik kredytowy, jest odpowiedzialny za podjęcie decyzji wyboru oferty i jej późniejszych konsekwencji [Czech 2018]. Ze względu na występującą nierównowagę kontraktową, ma ona szczególnie duże znaczenie dla słabszej strony umowy - klienta detalicznego [Gnela 2012: 175-176]. W związku z powyższym kredytodawca powinien zadbać i stworzyć odpowiednie warunki, które będą wspomagać proces decyzyjny konsumenta w procesie kredytowym.

\section{ISTOTA I ZNACZENIE JAKOŚCI OBSŁUGI KLIENTA W BANKOWOŚCI}

Dobra obsługa klienta bankowego jest sztuką, bo wymaga nie tylko merytorycznego przygotowania, ale też intuicji, wyczucia klienta, bystrości obserwacji i szybkiej oceny sytuacji, uważnego słuchania i rozumienia klienta oraz oddzielenia od swoich emocji czy ocen. Jest to pewnego rodzaju gra nastawiona na zrobienie najlepszego wrażenia na kliencie, sprawienie, aby czuł się zadowolony i usatysfakcjonowany i został stałym, lojalnym klientem.

Dlatego bankowcy, którzy są w bezpośredniej relacji z klientem powinni realizować sztukę profesjonalnej obsługi klientów.

Oznaką marketingowej orientacji banku są działania, które przede wszystkim mają na względzie potrzeby i oczekiwania klientów, a dotyczą m.in.: kształtowania oferty usług bankowych oraz organizacji i warunków obsługi klientów [Pluta-Olearnik 1999: 2-3]. W zakresie kształtowania oferty usług bankowych ważną rolę pełni doświadczenie oraz sugestie pracowników bezpośrednio obsługujących klientów, którzy mają wpływ w zakresie negocjowania indywidualnych warunków sprzedaży usługi. Organizacja i warunki obsługi muszą być również dostosowane do oczekiwań klientów i obejmują one zarówno rozwiązania dotyczące bezpośredniej obsługi przez pracownika banku (jego wiedza, za- 
chowanie i umiejętności sprzedażowe), jak i organizacji obsługi klientów w placówce. Celem marketingu usług bankowych jest prowadzenie działalności w taki sposób, aby klient odczuwał satysfakcję, a bank osiągał zyski [Ziomek 2010: 7]. Bank zorientowany marketingowo ma w centrum uwagi klienta i swoje usługi stara się dostosować do jego potrzeb i wymagań - teraz i w przyszłości [Żurawik i Żurawik 1996: 190]. Z literatury przedmiotu wynika, że rośnie średnia wartość nowo udzielanego kredytu konsumpcyjnego, a tym samym rośnie ryzyko kredytowe. Banki przesuwają ofertę finansowania konsumentów ku coraz wyższym kwotom [Nowak 2018a: 453].

Punktem wyjścia do kształtowania pożądanej jakości obsługi klienta banku jest poznanie jego potrzeb i przedstawienia oferty z punku widzenia korzyści, jakie może klient osiągnąć, bowiem klient jest zainteresowany maksymalizowaniem swoich korzyści z usług. Jednak pracownicy banku często patrzą jedynie przez pryzmat przyszłych korzyści dla banku oraz koncentrują się na technicznych aspektach swojej pracy zapominając o kliencie. W miarę ujednolicania ofert usług bankowych istotnym obszarem konkurencji staje się poziom jakości obsługi klienta.

Jak wynika z Monitora Satysfakcji Klientów Banków Detalicznych [Klienci banków najlepiej oceniaja..., dostęp: 15.05.2018], badania przeprowadzonego przez Instytut ARC Rynek i Opinia w 2016 r., klienci banków oceniając jakość usług świadczonych przez banki najwyżej ocenili nowoczesne sposoby komunikacji z bankiem: bankowość internetową i mobilną, a słabej tradycyjne formy kontaktu z bankiem: wizyta w oddziale czy infolinia. Z badania wynika, że im młodszy i bardziej wykształcony klient, tym mniejsze zadowolenie z usług bankowych. Osoby te są bardziej świadome swoich praw konsumenckich w relacjach z instytucjami finansowymi - wiedzą, czego mogą od nich oczekiwać i wymagać [Banki z najlepsza $i$ najgorsza obstuga klienta, 2016, dostęp: 11.05.2018]. W przypadku kontaktu klienta z bankiem kanałami tradycyjnymi największy wpływ na ocenę jakości obsługi ma czynnik ludzki i najwyżej oceniane są przez klientów: uprzejmość, zaangażowanie oraz chęć udzielenia pomocy przez konsultanta.

Badanie Instytutu Homo Homini [Dobra obsługa klienta..., 2011, dostęp: 14.05.2018] przeprowadzone w 2011 r. dla Deutsche Bank PBC pokazuje, że nie cena czy promocja oferty, ale jakość usług świadczonych przez bank, mają największe znaczenie dla poziomu zadowolenia jego klientów. Najbardziej istotnym składnikiem oferty banku, który decyduje o zadowoleniu z jego usług jest uprzejmość obsługi w oddziale - uzyskała ona 63 proc. wskazań respondentów. Kolejny ważny czynnik to wysoki poziom kompetencji pracowników placówki, który uzyskał 57,5 proc. wskazań, następny trzeci czynnik to funkcjonalność bankowości elektronicznej (52,8 proc.). 
Ogólnopolskie badanie przeprowadzone w 2016 r. przez firmę badawczą International Service Check [Ranking banków 2016 - jakość..., 2016, dostęp: 20.05.2018], wykazało, że obsługa klienta nadal w wielu placówkach bankowych wymaga dopracowania i profesjonalizacji usług. Ogólny średni wynik, jaki osiągnęły wszystkie przebadane banki, wyniósł 74,2 proc.

Powyższe badania empiryczne dowodzą, że istnieją duże różnice w jakości świadczenia usług pomiędzy bankami. W walce o lojalność klientów coraz bardziej liczy się jakość obsługi, a nie cena usługi (produktu). Pozyskiwanie klientów jest coraz trudniejsze i dlatego jakość obsługi jest tym, co przyciąga klienta i przyczynia się do wzmocnienia jego lojalności wobec banku. Badania wykazały stały trend, że dla konsumenta najważniejsza jest jakość obsługi tj. uprzejma obsługa oraz komfortowa, przyjazna atmosfera, a nie sposób i ilość przekazywanych informacji i wyjaśnień o danej usłudze bankowej (produkcie), które narzuca ustawodawca, m.in. w ustawie o kredycie konsumenckim.

\section{ANALIZA OBSŁUGI KLIENTA W PROCESIE KREDYTOWYM}

Analiza praktyki banków w zakresie obsługi klienta detalicznego w procesie kredytowym realizowanej przez wybrane banki została uzupełniona wynikami badań własnych. Celem badania było przedstawienie i ocena zachowań banków związanej z obsługą konsumenta na etapie przedkontraktowym na rynku kredytów detalicznych. Informacje zostały zebrane metodą „tajemniczego klienta”. Zastosowanie tej metody umożliwiło uzyskanie bezpośrednich danych i praktycznej wiedzy, o tym jak banki obsługują klientów oraz jak wywiązują się z licznych ustawowych obowiązków informacyjnych na etapie poprzedzającym zawarcie umowy o kredyt konsumencki, tzw. etapie przedkontraktowym.

Dobór banków został dokonany na podstawie danych o wartości portfela kredytów konsumpcyjnych i detalicznych dla osób fizycznych, posiadanego przez banki w 2015 r., opublikowanych przez miesięcznik „Bank” oraz na podstawie rankingu najlepszych banków tygodnika „Newsweek”. Badania zostały przeprowadzone na próbie złożonej z 10 dominujących banków działających na polskim rynku, mających na nim najsilniejszą pozycję w badanym zakresie kredytów detalicznych: PKO Bank Polski, Bank Pekao, Getin Bank, Bank BGŻ PNB Paribas, Deutsche Bank, Eurobank, Santander Consumer Bank, mBank, ING Bank Śląski i Bank Millennium. Badania przeprowadzono w maju 2017 r. zwracając się do banków o przedstawienie oferty na taki sam kredyt gotówkowy w kwocie 20 tys. zł na okres dwóch lat.

Ocenę zachowania banków w procesie kredytowym, z punktu widzenia wpływu na możliwość podjęcia przez konsumenta właściwej decyzji, przepro- 
wadzono w kategorii obsługa klienta. Stosunek banku do klienta został przebadany w 6 wymiarach (tab. 1):

- możliwość prowadzenia rozmowy w osobnym pomieszczeniu,

- proponowana kawa/herbata/woda,

- informacje objaśniane klientowi,

- informowanie o możliwości odstąpienia od umowy w ciągu 14 dni,

- narzędzia stosowane przy objaśnianiu oferty,

- poziom obsługi.

Tabela 1. Obsługa klienta detalicznego w wybranych bankach

\begin{tabular}{|c|c|c|c|c|c|c|c|c|c|c|}
\hline & Bank A & Bank B & Bank C & Bank D & Bank E & Bank F & Bank G & Bank H & Bank I & Bank J \\
\hline $\begin{array}{l}\text { możliwość prowadzenia } \\
\text { rozmowy w osobnym } \\
\text { pomieszczeniu }\end{array}$ & nie & nie & nie & nie & tak & tak & nie & nie & nie & nie \\
\hline $\begin{array}{l}\text { proponowana } \\
\text { kawa/herbata/woda }\end{array}$ & nie & nie & nie & nie & tak & nie & tak & nie & nie & nie \\
\hline $\begin{array}{l}\text { informacje objaśniane } \\
\text { klientowi: } \\
\text { tylko podstawowe }\end{array}$ & $x$ & & $x$ & $x$ & & $x$ & & $x$ & & $x$ \\
\hline - więcej niż podstawowe & & & & & & & $x$ & & $\mathrm{x}$ & \\
\hline - pelne & & $x$ & & & $\mathrm{x}$ & & & & & \\
\hline $\begin{array}{l}\text { informowanie o } \\
\text { możliwości odstappienia } \\
\text { do umowy w ciągu } 14 \text { dni }\end{array}$ & tak & tak & nie & nie & tak & nie & nie & tak & tak & nie \\
\hline $\begin{array}{l}\text { narzędzia stosowane } \\
\text { przy objaśnianiu oferty }\end{array}$ & \begin{tabular}{|c|} 
obszerny \\
formularz \\
informacyjny
\end{tabular} & $\begin{array}{c}\text { skrócony } \\
\text { formularz } \\
\text { własny/ } \\
\text { harmonogram } \\
\text { spłat }\end{array}$ & \begin{tabular}{|c|} 
obszerny \\
formularz \\
informacyjny
\end{tabular} & $(-)$ & $\begin{array}{l}\text { własny } \\
\text { program } \\
\text { komputerowy }\end{array}$ & $\begin{array}{l}\text { skrócony } \\
\text { formularz } \\
\text { własny }\end{array}$ & $\begin{array}{l}\text { skrócony } \\
\text { formularz } \\
\text { własny }\end{array}$ & $(-)$ & $\begin{array}{c}\text { obszerny } \\
\text { formularz } \\
\text { informacyjny }\end{array}$ & $\begin{array}{l}\text { obszerny } \\
\text { formularz } \\
\text { informacyjny }\end{array}$ \\
\hline poziom obsługi & niski & wysoki & niski & niski & wysoki & średni & wysoki & niski & średni & niski \\
\hline
\end{tabular}

Uwaga: w zakres „,informacji objaśnianych klientowi” wchodzą :

- tylko podstawowe: rata kredytu, oprocentowanie nominalne, prowizja,

- więcej niż podstawowe: podstawowe + całkowity koszt kredytu, całkowita kwota do zapłaty i RRSO, nie kredytu.

- pełne: więcej niż podstawowe + uwzględniające sytuację finansową klienta i przeznacze-

Źródło: badania własne.

W badaniu potencjalny klient był zainteresowany produktem kredytowym, ale dopiero w zależności od usłyszanych i przekazanych informacji oraz jakości obsługi, miał zdecydować się w przyszłości na zakup produktu lub nie. Informacje zebrane mają głównie charakter informacji udzielanych dobrowolnie i spontanicznie przez pracowników banku, a nie informacji wymuszonych na pracow- 
niku banku przez „tajemniczego klienta”. Oceny dokonano na podstawie rozmów przeprowadzanych z pracownikami banków w zakresie kredytu konsumenckiego, których efektem było otrzymanie najlepszej i satysfakcjonującej potencjalnego klienta oferty kredytowej. Wyniki badań w aspekcie jakości obsługi klienta detalicznego w wybranych bankach przedstawia tab. 1.

Pierwszy kontakt z klientem, czyli powitanie i umiejętność rozpoznania jego potrzeb według ankietera jest najsłabszą stroną pracowników banków. W interakcji z klientem pracownicy banku nie zawsze wstawali na powitanie i przedstawiali się, co negatywnie wpływało na postrzeganie danego oddziału banku. Pracownicy zwykle zauważali klienta od razu po wejściu do banku. Również obsługiwali niezwłocznie lub w akceptowalne kilka minut po wejściu do placówki, choć zdarzały się też rzadkie przypadki, w których na obsługę trzeba było oczekiwać zbyt długo.

Możliwość przeprowadzenia rozmowy w osobnym pomieszczeniu stwarza dobre warunki do zebrania informacji i zrozumienia oferty. Niestety tylko w 2 placówkach takie warunki istniały. Pod tym względem najlepiej wypadł bank E i F. W ich przypadku rozmowa została przeprowadzona w osobnym pomieszczeniu (saloniku), co znacznie podnosiło jej komfort i jakość obsługi klienta. W pozostałych przypadkach występował niski komfort prowadzenia rozmowy - hałas i presja ze strony innych klientów w kolejce. W przypadku banku $\mathrm{H}$ trzeba było czekać powyżej 15 minut na rozmowę, a w jej trakcie tworzyła się kolejka zainteresowanych osób. W takiej sytuacji automatycznie warunki się pogarszały i obniżał się drastycznie komfort rozmowy.

Tylko w dwóch bankach (E i G) doradca klienta zaproponował coś do picia na początku rozmowy. Ten gest ze strony pracownika można oceniać bardzo pozytywnie i interpretować jako gotowość poświęcenia klientowi czasu i chęć przeprowadzenia z nim dłuższej rozmowy.

W przebadanych przypadkach pracownicy banku w niskim stopniu interesowali się sytuacją klienta. W rozmowach pojawiało się wprawdzie pytanie o przeznaczenie kredytu, ale za tym pytaniem nie stała otwartość i gotowość szukania propozycji uwzględniającej rzeczywiste potrzeby klienta. Wynikało to albo z systemu, który prowadził pracownika banku w rozmowie, albo stanowiło przejaw sztucznej troski, tylko po to, aby w kolejnym kroku namawiać klienta na wzięcie większego kredytu. Pracownicy banków nie starali się zrozumieć potrzeb pożyczkowych klienta. Troska banku o klienta oparta była na zasadzie, żeby klient nie wziął za mało i aby mu nie zabrakło pieniędzy na realizację celu. Wyniki badań potwierdzają występujące nieprawidłowości, że banki realizują model biznesowy nastawiony na agresywną sprzedaż bez rzetelnej oceny sytuacji ekonomicznej klienta i jego potrzeb [Nowak 2017: 53-63].

Pracownicy banków podczas prezentacji produktu nie tłumaczą warunków oferty w sposób właściwy dla ochrony interesów klienta. Najczęściej udzielają 
informacji tylko na podstawowym poziomie, ograniczając wyjaśnienia do wysokości raty i oprocentowania. Moim zdaniem, informacja na temat wysokości oprocentowania jest na ogół bez większego znaczenia dla klienta i ma charakter czysto reklamowy, dlatego, że oprocentowanie jest tylko jednym z wielu składników kosztu kredytu. Najczęściej jest tak, że gdy oprocentowanie jest niskie to prowizja lub opłata przygotowawcza są wysokie, i odwrotnie - gdy oprocentowanie jest wysokie, to inne koszty są niskie.

$\mathrm{Z}$ kolei informacja na temat wysokości raty należy do jednych z najważniejszych - obok całkowitych kosztów kredytu. Podając informację na temat wysokości raty, pracownik banku powinien jednak poświęcić więcej czasu i troski na wyjaśnienia klientowi. Przede wszystkim zwrócić mu uwagę, że rata kredytu powinna być dopasowana do jego dochodów i wynieść jakąś rozsądną część miesięcznego dochodu - jeżeli rata będzie za wysoka, to klient może mieć problemy ze spłatą kredytu. Ponadto, jeżeli rata kredytu stanowi dużą część miesięcznego dochodu, bank powinien zwrócić uwagę klientowi na znaczenie oszczędności, z których ewentualnie mógłby pokryć ratę w przypadku braku lub spadku miesięcznego dochodu. Klient musi zdawać sobie sprawę, że jeżeli kwota kredytu ma pozostać taka sama, to stoi przed wyborem jednego z dwóch wariantów: niższa rata, dłuższy okres kredytowania i wyższe całkowite koszty kredytu, albo wyższa rata, krótszy okres kredytowania i niższe całkowite koszty kredytu. Podając te informacje pracownik banku może wykazać swoją przydatność i dopasować kredyt do potrzeb klienta.

Aby wystąpić w roli niezależnego doradcy, pracownik banku musi jednak wejść głębiej w sytuację klienta i przekazać mu kolejne informacje na temat możliwości wcześniejszej spłaty kredytu i związanych z tym korzyści i kosztów, gdy raty okażą się za niskie; a także możliwości i kosztów wydłużenia umowy w sytuacji, gdy raty okażą się za wysokie. Stawiając bankom pytanie, który $\mathrm{z}$ tych dwóch wariantów jest lepszy dla klienta, banki jednomyślnie opowiadają się za pierwszym wariantem, tzn. namawiają, aby wziąc kredyt z niższą ratą i jeżeli dochody pozwolą na wcześniejszą spłatę to nadpłacić kapitał. Jednak kredyt na dłuższy okres będzie droższy ze względu na wyższą prowizję.

Z kontaktów z bankami wynika, że informacja na temat całkowitych kosztów kredytu jest uwidaczniania w ofertach banków, ale banki niechętnie o niej mówią i nie koncentrują na niej uwagi klienta. Jest to niezgodne $\mathrm{z}$ interesem klienta. Pomijanie tej informacji można interpretować jako brak szacunku dla pieniędzy klientów. Całkowite koszty kredytu są ważne, ponieważ wskazują ile rzeczywiście kosztuje kredyt i na tej podstawie konsument może ocenić, czy opłaca się go brać, czy nie.

Informacja na temat RRSO była traktowana przez pracownikowi banków jako bez znaczenia dla klienta. Wskaźnik ten wprowadziła ustawa o kredycie 
konsumenckim właśnie po to, aby klienci mogli porównać zagmatwane warunki kredytu.

Niektórych elementów oferty pracownicy banków zazwyczaj nie byli w stanie wytłumaczyć. Dotyczyło to charakteru ubezpieczenia kredytu. Doradcy klienta nie potrafili wyjaśnić zrozumiale, co obejmuje ubezpieczenie kredytu, a jedynym argumentem za wzięciem kredytu z ubezpieczeniem było to, że jest on w ofercie banku tańszy niż bez ubezpieczenia, co powinno klientowi w zupełności wystarczyć. Bank I okazał się jedynym bankiem, który był przygotowany merytorycznie na przedstawienie oferty na ubezpieczenie i przekazał pełny zestaw dokumentów.

W zakresie „informacji objaśnianych klientom” pracownicy banków popełniają poważne błędy w kontaktach z klientem. Prowadzą rozmowę w sposób nieuporządkowany, bez właściwej hierarchizacji ważności poruszanych spraw. Poświęcają za dużo uwagi na sprawy drugorzędne, a zdecydowanie za mało na spawy zasadnicze dla klienta. Kontakty z bankami nie edukują ekonomicznie klientów. Trudna dla zwykłego klienta terminologia fachowa powinna być przedstawiona w sposób jak najbardziej jasny i zrozumiały, dlatego przy bezpośredniej obsłudze klienta warunkiem koniecznym jest komunikatywność pracownika banku [Ziomek 2010: 19].

Bankowcy mieli również problemy $\mathrm{z}$ ewentualnym sfinalizowaniem sprzedaży, tj. przedstawieniem ostatecznej oferty kredytowej w pełni dopasowanej do potrzeb i wymagań klienta $\mathrm{z}$ wszystkimi niezbędnymi wyjaśnieniami pojęć. W trakcie obsługi dość sprawnie załatwiano formalności oraz zachęcano do zapoznania się i przeczytania dokumentów. Z badań wynika, że więcej niż połowa banków thumaczyła klientowi informacje wchodzące w skład oferty tylko na poziomie podstawowym, najczęściej opierając wyjaśnienia tylko na wydrukowanym formularzu informacyjnym. Tylko wyjaśnienia 4 banków były na poziomie wyższym niż podstawowy, w tym w 2 bankach (I i G) były to informacje więcej niż podstawowe, a w kolejnych 2 bankach informacje pełne (B i E).

W kategorii „obsługa klienta” brano pod uwagę także odpowiedź na pytanie: czy bank informuje klienta o możliwości odstąpienia od umowy? Informując o takiej możliwości bank daje do zrozumienia klientowi, że ma czas do namysłu i może wycofać się z transakcji nawet po podpisaniu umowy. W ten sposób pracownik banku poprawia klientowi komfort podejmowania decyzji. Informacja o możliwości odstąpienia od umowy w ciągu 14 dni bez żadnych konsekwencji dla konsumenta, zgodnie z ustawą o kredycie konsumenckim, została przekazana na tym etapie procesu kredytowego tylko przez 5 banków.

Analizując wyniki dla przebadanych placówek banków, nieprzeciętnie wysoką jakością obsługi wyróżniły się szczególnie trzy oddziały: E, G i B. Na uwagę zasługuje prezentacja oferty kredytowej przez bank E, gdzie doradca ds. sprzedaży detalicznej za pomocą programu komputerowego banku w sposób 
zrozumiały przedstawił ofertę kredytową. Również pracownik banku G w sposób atrakcyjny przedstawił ofertę, używając formularza „Finansowanie moich planów" i poinformował o ,gwarancji najniższego oprocentowania”. W obsłudze klienta wyróżnił się także bank I, gdzie klient otrzymał różne symulacje kredytu przy zmianie stopy oprocentowania oraz bank B, który jako jedyny zawarł w ofercie harmonogram spłat.

Natomiast na ogół pracownicy starali się rozpoznać potrzeby klienta, pytając o posiadane $\mathrm{w}$ banku produkty i oczekiwania w celu przeprowadzenia działań marketingowych. Również kategorii ,produkty dodatkowe” można wystosować pewne zastrzeżenia do pracowników banków objętych badaniem, ponieważ można oczekiwać, że dodatkowe produkty bankowe (np. ubezpieczenie, lokata, karta kredytowa itp.) są często proponowane i reklamowane przez doradców przy obsłudze klienta, tymczasem wyniki badania pokazują odwrotną tendencję. Liderem w zakresie ilości informacji na temat usług dodatkowych był bank G. Pracownik banku zaoferował „Konto 360 ”, dwa rodzaje kart kredytowych: Alfa i Impresja oraz konto oszczędnościowe Profit. Wszystkie te produkty zostały w sposób zrozumiały zaprezentowane i do każdego z nich dołączona została odrębna ulotka informacyjna. Natomiast bank E poświęcił klientowi czas i próbował znaleźć produkty dodatkowe dopasowane do potrzeb i oczekiwań klienta.

Zakończenie wizyty to ostatnia chwila, kiedy pracownik banku może zapisać się dobrze w pamięci klienta. Na tym końcowym etapie interakcji z klientem najlepiej wypadł bank E, G, B i I. W tych bankach ,tajemniczy klient” był żegnany uprzejmie, zapraszano go do ponownego odwiedzenia oddziału, otrzymał teczkę ze stosownymi dokumentami oraz wizytówkę od doradcy.

Na podstawie badania można wskazać również pozytywne aspekty obsługi w oddziałach bankowych. Docenić należy głównie wygląd zewnętrzny i wewnętrzny placówek oraz kulturę osobistą pracowników. W przypadku pracowników, zasady wyglądu w praktyce były mniej lub bardziej sprecyzowane, ponieważ nie we wszystkich placówkach obowiązywał ujednolicony strój. Natomiast dało się zaobserwować konsekwentne i profesjonalne podejście do zewnętrznego wizerunku placówek, w których była stosowana wizualna identyfikacja.

Pierwsze odczucie odgrywa ogromną rolę w kontakcie z bankiem, ponieważ decyduje o tym, jakie klient wyrobi sobie wrażenie o pracowniku i o banku.

\section{PODSUMOWANIE}

Doradca w oddziale jest najważniejszą wizytówką banku, a jego kompetencje, profesjonalizm i uprzejmość rzutują na wizerunek całej instytucji w oczach klienta. Bankowcy są najważniejszymi pośrednikami w przekazywaniu informacji, stanowią istotny element procesu tworzenia i świadczenia usług bankowych 
od strony jakościowej, a ich zaangażowanie, umiejętności i wiedza wpływają na odczucia klientów odnośnie oferowanych usług i całego banku [Kałużny i Kałużna 1996: 46]. Konkluzje zawarte w artykule potwierdzają, że występuje brak odpowiedniego przygotowania merytorycznego osób zaangażowanych w proces sprzedaży, co uniemożliwia odpowiednią ocenę możliwości ekonomicznych klienta [Nowak 2018b: 199-210].

Analiza badań własnych potwierdziła zaniedbania banków w obsłudze klienta detalicznego w fazie przedkontraktowej i wykazała:

- niski poziom wyjaśnień udzielanych przez pracowników banków klientom (w ponad połowie przypadków informacje objaśniane przez pracowników banków były niepełne i dotyczyły tylko wysokości raty i oprocentowania),

- niską dbałość w zakresie budowania oferty i form obsługi (tylko w dwóch bankach zastosowano skrócony formularz własny, co przyczyniło się do zmniejszenia negatywnych konsekwencji tzw. przeładowania informacyjnego),

- stosowanie zachowań sprzecznych z dobrymi obyczajami obsługi (zaniedbywanie obowiązków informacyjnych, pomijanie istotnych informacji i brak tłumaczenia warunków ofert w sposób właściwy dla ochrony konsumenta),

- realizację przez banki modelu biznesowego nastawionego na sprzedaż kredytów detalicznych (w niskim stopniu interesowali się sytuacją i rzeczywistymi potrzebami klienta),

- częsty brak odpowiednich warunków lokalowych do przeprowadzania rozmowy i zapoznania się w spokoju z przekazywanymi informacjami (tylko w dwóch na dziesięć przypadków istniały komfortowe warunki do przeprowadzenia poufnej rozmowy),

- nie informowanie klienta o ustawowo gwarantowanych prawach konsumenta ściśle związanych z umową o kredyt konsumencki (w połowie przypadków została podana informacja o prawie odstąpienia od umowy w ciągu 14 dni).

Tym samym postawiona teza, iż banki w procesie kredytowym $\mathrm{w}$ trakcie obsługi klientów detalicznych nie biorą pod uwagę w wystarczającym stopniu interesów konsumentów i nie wywiązują się z wszystkich obowiązków przedkontraktowych, dlatego udzielane informacje, przekazywane dane i wyjaśnienia nie są dla konsumenta wystarczające w podejmowaniu właściwych decyzji finansowych, została potwierdzona. 


\section{BIBLIOGRAFIA}

Banki $z$ najlepsza $i$ najgorsza obstuga klienta, 2016, ARC Rynek i Opinia, http://bank24.blox.pl/2016/09/Banki-z-najlepsza-i-najgorsza-obsluga-klienta.html [dostęp: 11.05.2018].

Czapliński M., 2012, Nie taki kredyt straszny. Ustawa o kredycie konsumenckim w pytaniach i odpowiedziach, Urząd Ochrony Konkurencji i Konsumentów, Warszawa, sierpień 2012, https://www.uokik.gov.pl/download.php?plik=12259 [dostęp: 07.05.2018].

Czech T., 2018, Komentarz do art.11 ustawy o kredycie konsumenckim, [w:] T. Czech, Kredyt konsumencki komentarz, Wolters Kluwer Polska.

Dobra obshuga klienta to $w$ banku podstawa, 2011, Homo Homini, http://www.egospodarka.pl/73948,Dobra-obsluga-klienta-to-w-banku-podstawa,1,39,1.html [dostęp: 14.05.2018]

Dyrektywa Parlamentu Europejskiego i Rady 2008/48/WE z dnia 23 kwietnia 2008 r. w sprawie umów o kredyt konsumencki oraz uchylająca dyrektywę Rady 87/102/EWG, Dyrektywy europejskie (Dz.U. 2014, poz.1497).

Gnela B., 2012, Prawo handlowe dla ekonomistów, Wolters Kluwer Polska, Warszawa.

Kałużny S., Kałużna H., 1996, Bankowiec \& Klient technologia, kultura, etyka, Centrum Szkoleniowo - Wydawnicze KWANTUM, Warszawa.

Klienci banków najlepiej oceniaja bankowość internetowa, 2017, ARC Rynek i Opinia, http://www.arc.com.pl/klienci_bankow_najlepiej_oceniaja_bankowosc_internetowa40999604-pl.html [dostęp: 15.05.2018].

Nowak P., 2017, Nieprawidłowości w ocenie zdolności kredytowej klientów detalicznych, „Finanse i Prawo Finansowe", nr 2(14), Łódź.

Nowak P., 2018a, Brak dostępu do kredytu jako przejaw wykluczenia finansowego, [w:] D. Murzyn, J. Pach, Ekonomia społeczna, Difin, Warszawa.

Nowak P., 2018b, Ocena zdolności kredytowej jako narzędzie ochrony konsumenta, [w:] M. Jagielska, K. Podgórski, E. Sługocka-Krupa, M. Fras, Prawa konsumenta w teorii i praktyce, C.H. Beck, Warszawa.

Ofiarski Z., 2014, Komentarz do art.11 ustawy o kredycie konsumenckim, [w:] Z. Ofiarski, Ustawa o kredycie konsumenckim. Komentarz, LEX.

Pluta-Olearnik M., 1999, Marketing ustug bankowych, PWE, Warszawa.

Poradnik dla konsumentów. Kredyt konsumencki. 2012, Urząd Ochrony Konkurencji i Konsumentów, Warszawa, https://uokik.gov.pl/download.php?plik=12551 [dostęp: 10.05.2018].

Ranking banków 2016 - jakość obstugi klienta, 2016, International Service Check, http://biznes.interia.pl/finanse-osobiste/news/ranking-bankow-2016-gdzie-mozna-liczyc-nanajlepsza,2427707,4141 [dostęp: 20.05.2018]

Szaraniec M., 2017, Działalność gospodarcza pośredników ubezpieczeniowych, Difin, Warszawa.

Tereszkiewicz P., 2009, Przedumowne obowiąki informacyjne instytucji kredytowych $w$ dyrektywie 2008/48/WE, „Europejski Przegląd Sądowy”, nr 12.

Tereszkiewicz P., 2012, Obowiązek udzielenia wyjaśnień $w$ unijnym i polskim prawie kredytu konsumenckiego na gruncie dyrektywy 2008/48/WE, [w:] J. Pisuliński, P. Tereszkiewicz, F. Zoll (red.), Rozprawy z prawa cywilnego, własności intelektualnej i prawa prywatnego międzynarodowego, Warszawa.

Tereszkiewicz P., 2014, Obowiązki informacyjne w umowach o uslugi finansowe, Wolters Kluwer Polska, Warszawa.

Ustawa z dnia 12 maja 2011 r. o kredycie konsumenckim, t.j. Dz.U. 2018, poz. 993 ze zm. 
Ziomek E., 2010, Obstuga klienta indywidualnego w bankowości na przykładzie banku Millennium S.A, Promotor, Warszawa.

Żurawik B., Żurawik W., 1996, Marketing bankowy, Biblioteka Menedżera i Bankowca, Warszawa.

\title{
RETAIL CUSTOMER SERVICE IN THE CREDIT PROCESS AT THE PRE-CONTRACT STAGE
}

\begin{abstract}
The conditions to take the right credit decision forms not only price, but also support of the bank. Fairly and properly carried out customer credit process is in the interest of the lender and borrower. It can protect both parties of the loan agreement before negative consequences. Consumer against over-indebtedness and financial troubles, and the bank against troubles of loan repayment. Quality of service is particularly import for the weaker party of the contract the retail client. The aim of the article is to evaluate the banks practice in terms of retail customer service at the pre-contract stage in the credit process. The article analyses the quality and reliability of the retail customer service and implementation obligations at the major banks in 2017. The conclusions of the studies indicate numerous irregularities in the course of handling clients attributable to banks. The conclusions contained in the article confirm that banks in the credit process do not take in account consumer interests to a sufficient degree and not fulfill of all pre-contract obligations.
\end{abstract}

Keywords: consumer credit, customer bank care, disclosure requirements, obligations at the precontract stage, consumer protection, credit process at the pre-contract stage. 